\title{
ALEVIS IN GERMANY AND THE POLITICS OF
}

RECOGNITION

\section{new}

\section{perspectives on}

\section{turkey}

Spring-Fall 2003

\section{Martin Sökefeld*}

Introduction: The Discourse on Immigrants in Germany

Migration has been among the most decisive influences shapins contemporary German society, deeply influencing not only economics and demography but also societal discourse and political practice. Legal issues concerning foreigners and immigration have been hotly debated in German society and have played a central role in many elections at both federal and provincial levels. Recognition is an issue at the heart of these concerns. How are migrants viewed in Germany, as "immigrants" or as "foreigners"? As individuals who form a legitimate part of German society, or who have overstayed their temporary "invitation"? Who contribute to the economy and to public welfare, and or who live at the expense of German society? Who are essentially alien to German society and can at best achieve a liminal state of betweenness, or who actively and self-consciously assume a diversity of positions at all levels of society?

For Germany these are also questions of self-recognition, questions whose broad range can be summarized in the single question, whether or not Germany is a country of immigration. Outsiders may wonder why this matter is so hotly debated. Yet as Christian Joppke (1999, p. 62) has remarked, this is not a question that can be answered at an empirical level-for example, by simply citing numbers of immigrants. It is also a symbolically loaded normative issue. It is not about what Germany is, but about what it should be, and what it is in essence. And although "essentialism" in various forms has been stringently critiqued, it remains a frequently encountered and powerful form of argumentation in discourses about identity. Andreas Wimmer (2002) has recently emphasized that practices of exclusion and discrimination-of othering, I would add-are at the very core of the idea of the nation

* Assistant Professor, Institute of Social and Cultural Anthropology, University of Hamburg. 
state; they are not just its accidental excesses. In contemporary Europe, after decades of efforts towards supranational integration, the "others" of the various nation-states are henceforth not external enemies, as in earlier times, but rather people of foreign origin living amongst the members of the nation. Thus the "other" that serves to define the self by contrast has been-at least geographically-internalized.

Varying degrees of otherness are ascribed to the different immigrant groups which have entered the country since labor migration began in the 1950s. Being Muslims, immigrants from Turkey are perceived as being "more different" than, say, Italians or Portuguese. In some cases, "Turk" almost seems to serve as a synonym for "foreigner" since, in their difference, Turks exemplify the very essence of foreignness. From this point of view, immigrants from Turkey are the paradigmatic others of the German nation.

Identity politics generally work with large, rough distinctions. In spite of interest in such topics as hybridity and crossing over in academic discourse as well as in some realms of the arts and popular culture ${ }^{2}$ these concepts are frequently (re-)constructed in a public discourse that equates difference with difficulty. In short, immigrants are essentialized as a problem. In the case of Turks, this problem is embodied not only in religion but also in language. Recent debates on the necessity for (and difficulty of) integrating foreigners in Germany centered on the issue of language acquisition, and included demands that immigrants learn German. These debates nearly created the impres sion that Turks in general resist learning the local language-it was rarely mentioned that earlier Turkish "guest workers" had actually been discouraged from learning German because they were expected to return to their "home country." Similarly, Turkish-language media in Germany are often identified as a problem because it is assumed that they prevent immigrants from learning German and integrating into German society, and perpetuate a "Turkish" orientation, tying immigrants to a "homeland perspective."3

1 Similar arguments opposing Muslim traditions to those of Christians were raised in late 2002 in Germany as part of the debate on Turkey's prospective EU membership.

2 See, for example, Bhabha (1994). See also Çağlar's critical perspective on hybridity (1997)

3 Althe recent studies have abandoned this assumption (see Weiß and Trebbe, 2001, and Wilamowits-Moellendorff, 2002), it still has great currency in
The predominant German view on migrants and migration, both in politics and in the academy, has been firmly based on "methodological nationalism" (Wimmer and Glick Schiller, 2002), an approach that naturalizes national boundaries and problematizes migrants because they transgress boundaries and the whole "national order of things" (Malkki, 1997, p. 55). The debate on the "integration" of foreigners in Germany is framed in terms that demand an either/or decision, either for total integration (assimilation) into German society, or for retaining attachments to the "home country," which make migrants perpetual strangers in the "host society." Only recently have approaches towards transmigration and transnational social spaces which allow for the possibility that migrants might have multiple attachments, thus rejecting the either/or option, been introduced into German academic debates (cf. Pries, 1997; Faist, 2000). In political discourse, however, methodological nationalism has not yet been fundamentally challenged.

This paper deals with the politics of identity that Alevi migrants from Turkey and their organizations have developed within, and in part against, the German migration discourse as roughly summarized above. It is based on research on local Alevi organizations in Hamburg as well as on the activities of the Federation of Alevi Communities in Germany, the Alevi umbrella organization located in Cologne. ${ }^{4}$ The Alevi case is of particular interest because it shows that an orientation towards "integration" and a strong "homeland perspective" are not necessarily mutually exclusive. As the Alevi example will show, a "homeland perspective" need not prevent "integration" in German society; rather, both perspectives may develop interdependently. Moreover, the Alevi politics of difference as practiced in Germany have made Alevis recognizable as a separate community through reference to universalistic values emphasizing differences between Alevis and other Turkish immigrants. This strategy has facilitated the granting of a measure of institutional integration to the Alevi community of Germany, which in has turn yielded resources for a transnational politics of identity aiming at formal recognition of Alevis in Turkey. Alevi efforts to be recog-

public discourse on migration; see also Becker and Behnisch (2001). Aksoy and Robins (2000 and 2002) have argued that the study of migration and the media must go beyond approaches centering on categories of nation and community.

4 Fieldwork was carried out from 1999 through 2003 and extended also to other locations in Germany and in Turkey. 
nized as equal citizens in Germany, and efforts to achieve some degree of institutional integration (the latter process strongly influenced by the institutional character of German society; see Soysal, 1994), has made possible the opening up of a transnational space for identity politics. This strategy has made use of the changing state of relations between Turkey and the European Union as a major referent, and has consciously evolved alongside these relations. The Alevi struggle thus extends beyond relations within and between two nationally defined states.

\section{Politics of Recognition}

I subsume this case of identity politics under the rubric "politics of recognition," because recognition in a twofold sense-as equal and as different-lies at its core. Recognition in both these senses is sought by Alevis in Turkey as well as in Germany. Allowing for some simplification it can be said that in Germany, Alevis primarily seek recognition as equals, as equal citizens, whereas in Turkey, recognition of the differences between Alevis and other compatriots is more important.

Scholarship and opinion on the issue of recognition have largely dealt with the problem of recognizing cultural minorities and granting these minorities specific legal privileges enabling the preservation of their cultures. In an influential essay, Charles Taylor (1994) derives the necessity for recognition from a specific, modern idea of identity according to which an individual's identity is not fixed by being born into a particular position within a ranked, hierarchical society, but has to be worked out individually as well as within bounded collectivities. According to Taylor, a need for recognition is implicated in a politics of dignity which attempts to bridge the paradox that universal human dignity is attributed on the basis of individual personality and idiosyncrasy, while at the same time, difference is celebrated along with the preservation of presumably shared features ("culture") which distinguish groups from one another. Current discussions on the politics of recognition, most frequently situated within a multiculturalist framework, have attributed more relevance to this second aspect. Here, the hotly debated question has been whether a liberal democracy should recognize and "protect" certain cultures to the extent of establishing legal definitions of difference in order to ensure their continuity. Taylor offers the example of
Franco-Canadian culture in Quebec in this context. In his critique of Taylor's approach, Gerd Baumann (1999) has rightly pointed out that it is not preexisting cultures, endowed with inherent rights, that demand recognition and protection, but that cultures can be created by particular agents, often those in elite positions, in the very struggle for recognition. 5

Taylor's position is an attack on the liberal political theory that recognizes equal rights only among individuals and considers collective rights granted to minorities as a restriction on and violation of the equality of individuals. Against this liberalism, Kymlicka (1995) raises the argument that the "benign neglect" supposedly inherent in liberal democracy, which treats all citizens as equals and disregards cultural differences, is not actually benign since "equal rights" affect citizens differently in their diverse and unequal positions. Law is never neutral, but reflects the cultural standards and values of the dominant section of society while minimally concerned with those of others. Habermas (1997), in contrast, argues that the solution to this inequality cannot be found in a kind of "cultural protection of the species" by law, but rather in procedural provisions that ensure the articulation of disadvantaged positions on the basis of equal individual participation.

Although the question of legal protection of cultures has dominated the debate on recognition, it is not the most important issue in the German Alevi case. When Alevis in Germany demand recognition they do not seek a kind of protective discrimination, but rather voice their demands as a universalistic claim for equality, referring to universal human rights and a universal humanist essence. According to Soysal (1994, p. 116), referring to universalistic arguments has become a strategy of Muslim migrant organizations in Europe more generally. However, in contrast to Alevi organizations, Islamic organizations often use such arguments in order to forward particularistic demands such as the right to wear the headscarf in schools or to slaughter animals according to Islamic rites. Alevis make no demands comparable to these. The claim for recognition of Alevis qua Alevis in Turkey includes the demand for the elimination of a form of religious discrimination practiced by the majority, embodied most visibly in the government's religious affairs agency, the Directorate for Religious Affairs

5 For Taylor's example of Quebec, see Handler (1988), who analyzes how Franco-Canadian culture is constructed through identity politics. 
(Diyanet İsleri Başhanlığl). ${ }^{6}$ The Alevi perspective holds that this agency protects only Turkey's Sunni Muslim majority and discriminates against them; Alevis are simply disregarded or, rather, officially subsumed without differentiation within the fold of Sunni Islam.

It is, of course, a gross simplification to speak of "the Alevi perspective," since the question of "what Alevism is" may be answered in a multitude of ways. To begin with, an important binding force among Alevis is the historical perspective that represents Alevis as marginalized, as suffering discrimination and even persecution at the hands of Sunni Muslims, throughout history. Yet since this is not the place to repeat accounts of Alevi history, ${ }^{7}$ suffice it to say that as a consequence of marginalization and discrimination Alevis resorted to what they call takiya, a strategy of intended dissimulation. Following this strategy, Alevis have generally held their rituals in secrecy and tried to pass as Sunnis within the larger non-Alevi public.

The present position of Alevis in Turkey is ambivalent. On the one hand, Alevism is no longer a matter of secrecy. Alevis can practice their religion freely, and since the early 1990s there is a widespread media discourse about Alevism (Vorhoff, 1995). This is the consequence of political changes as well as of the Alevi movement which, since the late $1980 \mathrm{~s}$, has struggled for legal recognition of Alevism in Turkey. ${ }^{8}$ On the other hand, however, Alevism is still silenced in official discourse, reflecting the lack of any form of formal recognition. As with other culture-based groups, Alevi organizations have largely been denied formal registration by the authorities if they carried the word "Alevi" in their name or if their by-laws refer explicitly to Alevism. This is due to the Turkish law on associations which prohibits organizations based on the assertion of cultural identity or differentiation within the Turkish nation. Associations created on the basis of, for example, Alevi or Kurdish identity, are seen as a violation of the unitary state presumably founded upon universalistic principles-and ultimately as sepa-

6 This applies at least to the majority of Alevi organizations in Turkey. Among the larger organizations, only Cem Vakf $i$ calls for Alevi representation within the Diyanet İleri Baskanly this constituting one of the most important differences Diyane torleri Baskanhy, this constituting one of the rest important differences between this and other organizations. Also, Cem Vahf has not becme a member of the Turkish Alevi umbrella organization, the Alevi Bektaşi Federasyonu, which was formed in 2002

7 For a comprehensive account, see Dressler (2002).

8 On the Alevi movement in Turkey see Vorhoff (1955 and 1998), and KehlBodrogi (1992 and 1993). ratism, the most serious political accusation in Turkey. Officials prefer to remain vague and evasive about Alevism. In August 2000, for instance, Turkey's liberal president Ahmet Necdet Sezer attended the opening ceremony of the annual Alevi festival in the central Anatolian town of Hacı Bektas together with many other politicians. ${ }^{9}$ In his opening speech President Sezer invoked freedom of religion but avoided using the words "Alevi" or "Alevism." Such an approach is symptomatic of the uneasy and equivocal position of the Kemalist state toward the Alevis: they may be honored by the presence of high officials at their events but are at the same time denied explicit and formal recognition, for instance as a religious community on legal par with the Sunni majority. This lack of official recognition naturally fosters insecurity among Alevis in Turkey, which is reinforced by the strong current of (Sunni) Islamist policy and by the number of instances of violence against Alevis that have occurred over the last decades. As a consequence, many continue takiya on an individual basis and are reluctant to identify publicly as Alevis. Most also share a perspective that identifies the history of Alevism with a chain of violent acts against their members, a chain that links the battle of Kerbela in 680 which marks the early schism in Islam, via the persecution of Alevis during Ottoman times (when they were known as Kizllbas), with recent events occurring in Maraş (1978), Sivas (1993), and Istanbul (1995).

\section{From Dissimulation to a Politics of Difference: Alevis in Germany}

Alevi migration to Germany from Turkey has been motivated by two major factors, economic (employment opportunity) and political. These reasons for migration entailed recourse to different legal avenues for immigration, while changing circumstances in Turkey engendered a diversity of motivations for emigration over time. Labor migration started in 1961, following an agreement for recruiting workers concluded between the German and Turkish governments. ${ }^{10}$ Like Sunni Turks, many Alevis emigrated to Germany after migrating from villages in Central and Eastern Anatolia to the cities of Istanbul or Ankara. Migration of this category was halted by the ban on recruitment issued

9 See Sinclair-Webb (1999) for an analysis of the festival in Haci Bektas

10 See Jamin (1999) for the conditions of this agreement and early immigration. 
by the German government in 1973. Politically motivated migration began within a few years after this, sparked by the tendency toward violent political polarization between extreme left and right wings; this form of migration reached its peak following the military coup of 1980 . During this period many Alevis had been active in leftist organizations.

A second phase of politically motivated migration began in the late 1980s, caused by the intensifying war between the Turkish army and the Kurdish separatists of the PKK, bringing Kurdish Alevis engaged in or affected by the conflict to Germany. Both labor and political migration were followed by migration via the legal avenue of family reunification, which allows for the immigration of spouses and minor children under certain conditions. This pattern of diverse avenues of migration does not distinguish Alevis fundamentally from Sunni Turkish migrants in Germany. Yet some Alevis argue that they were disproportionately affected by the first period of political migration because Alevis identified with the left side of the political spectrum and it was the leftists who suffered persecution after the coup. The German administration made no distinction between Sunni and Alevi immigrants from Turkey, since this distinction was neither known nor relevant in the legal context. Consequently there are no statistics on the numbers of Alevis in Germany. Estimates by Alevi organizations vary from 500,000 to $700,000,11$ but this may be a reflection of the politics of numbers in Turkey, according to which Alevis estimate their population at a fourth to a third of the total, while non-Alevi sources cite much lower figures. Nor, for some time, was the difference between Alevis and Sunnis known within the German public; and initially, neither Alevis nor Sunnis did anything to make it known. Alevi migrants in Germany largely maintained the strategy of takiya. I collected a number of stories from young Alevis who even in the late 1980s and 1990s had not been told by their parents that they were Alevis, mostly because their parents feared discrimination by Sunni Turkish immigrants.

Within a few years after their arrival in Germany, the Sunni Turkish community had begun to build mosques. ${ }^{12}$ In order to avoid

11 At present, roughly 2 million persons with Turkish citizenship are living in Germany. However, this number cannot serve as a basis for calculating the proportion of Alevis since German statistics mention only citizenship. Also, many Alevis have naturalized and are therefore not counted as Turks (see below, section
"Institutional Integration and Difference," fn. 20).

12 In Hamburg, for instance, the first Turkish mosque was constructed by 1969 (Mihçıyazgan, 1990, p. 11) reification of the differences between Alevis and Sunnis it should be emphasized that by no means were all Sunni migrants religiously oriented and engaged in religious institution-building. However, the fact remains that there were no comparable efforts among Alevis to establish a religious life in the new country of residence. This was due not only to the continued practice of dissimulation and to a generally weaker religious orientation among many Alevis, but also to the circumstance that Alevi religious institutions cannot be easily relocated. The Alevi ritual cem which is at the center of Alevi spiritual life takes places less in a particular spatial and architectural structure, such as offered by a mosque, than in a specific social structure consisting of hereditary networks of religious leaders (dedes) and their followers (talips). A cem can be held only by a dede together with his particular congregation of talips. The dede-talip networks that had already been stretched and strained by internal migration in Turkey were damaged even more severely by international migration. In Germany it was thus impossible to bring together the congregations necessary for conducting the cem. ${ }^{13}$

Alevis did not tend to form religion-based associations in Germany, but from the mid 1970s onwards, many participated actively in political organizations. As with the political leanings of Alevis in Turkey, these organizations were situated on the left side of the political spectrum. Labor migrants overall were most likely to belong to parties and organizations of social democrat orientation, but while some Alevis became members of the German social-democrat party SPD, most participated in expatriate wings of Turkish parties. Thus, Alevis were among the founders of HDF (Halkçı Devrimci Federasyonu, Popular Revolutionary Federation), the expatriate support organization of the social-democrat CHP (Cumhuriyet Halk Partisi, Republican People's Party), the party originally founded by Atatürk. The refugees of the late 1970 s and early $1980 \mathrm{~s}$, however, committed themselves to radical leftist groups like Dev Yol (Revolutionary Path). ${ }^{14}$

The Alevi-Sunni distinction was not significant within any of these organizations; in fact, radical leftist Turkish Alevis were, rather, engaged in erasing that differentiation. Marxist teachings declared

13 On later developments regarding the cem and dedes in Germany see Sökefeld, 2002a, in press

14 See Özcan (1992) on the political organizations of Turkish migrants in Germany, 
religion an obstacle to progress, thus, to insist on being Alevi would have been tantamount to taking a reactionary stance. Elements of Alevism did play a certain role in leftist movements because they were sometimes presented as a historical antecedent of socialism. In that context a very limited image of Alevism was constructed, and it was by no means supposed that Alevism as a religious teaching should be followed. In the early 1970 s, young radical Alevis had already been engaged in driving Alevism out of their villages by denouncing dedes as exploiters of the people and preventing them from conducting the cem. Over the course of the decade, the difference between Alevi and Sunn became, to a great extent, coincident with the distinction between the extreme left and the extreme right.

It was in late 1978 that the Alevi-Sunni distinction became significant for the first time within Turkish political organizations in Germany The ultra-nationalist MHP (Milliyetçi Hareket Partisi, the Nationalist Action Party) had instigated a number of violent attacks against leftists (i.e. Alevis) in various Turkish cities. In late December 1978 it provcked large-scale violence against Alevis in the southeastern Anatolian town of Maras, where more than a hundred Alevis were killed (Sinclair-Webb, 2003). Alevi members of the HDF in Hamburg demanded that their committee voice protest against this massacre, but the organization's leaders refused to do so because the Turkish government was headed at that time by Bülent Ecevit of the CHP and they did not want to criticize their own government. As a consequence, forty Alevi members of the Hamburg branch of the HDF resigned in early 1979 in order to found their own organization. Together with supporters of the Türkiye Birlik Partisi, an Alevi party in Turkey, they established the Yurtseverler Birliğ $i$ (Union of Patriots) as an association of Alevis. Although the Yurtseverler Birliğ was closed in 1984 following the military coup in Turkey, its activists organized the first public cem in Hamburg in that same year. Halis Tosun, one of the main activists of the early Alevi movement in Germany, recounts in his memoirs that the move towards separate Alevi organizations caused great consternation among the radical left organizations as well (Tosun, 2002, p. 34). However, it is important to note that these developments closely paralleled Alevi politics in Turkey: the word "Alevi" was not explicitly used in public, and there was no overt demand for Alevis' being recognized as a separate community.
The short-lived Yurtseverler Birliği went unnoticed by the German public, confined as it was to the "homeland" oriented politics of Turkish immigrants. Yet at the same time migration from Turkey increasingly became a public issue in Germany. Immigrants were asked to "go home," and the government of chancellor Helmut Kohl even sponsored their repatriation. Racist violence against immigrants became virulent-in Hamburg, two Turks were murdered by skinheads in 1985. In opposition to both popular racism and official policies against foreigners, a discourse of multiculturalism emerged which, in cities like Frankfurt and Hamburg, became embodied to some extent in public institutions.

In Hamburg, the senate sponsored a number of intercultural centers in districts with high numbers of migrants, which attracted the participation of some Alevis. At the same time, many activists within Turkish immigrants' political organizations turned from purely Turkey-oriented exile activities to a perspective of engagement in Germany. For instance, a Turkish parents' council was formed to deal with difficulties experienced by Turkish pupils in the schools. Among Marxist exile organizations the revolutionary spirit had waned. Dev Yol was finally dissolved and some of its former activists turned to multiculturalist politics in pursuit of equal rights and the recognition of cultural identities in Germany. In Hamburg, Alevis became active in various areas of the new multiculturalist politics as practiced at the recently founded intercultural centers. Yet alongside their multiculturalist activities in Germany they still monitored the political situation in Turkey.

Two developments in Turkey especially caught their attention: first, state-sponsored pressure towards "Sunnification" (Jongerden, 2003, p. 80 ), perceived, for instance, in the compulsory (Sunni) religious instruction in the schools, paralleled a rise of Islamist politics more generally. The second development was the militant struggle of the Kurdish Workers Party (PKK) for the recognition of Kurdish identity and the establishment of a Kurdish state. Alevi activists in Hamburg came to the conclusion that not only Kurdish but also Alevi identity remained unacknowledged and were endangered in Turkey. Thus, in Germany, multiculturalism should not only strive for the recognition of Turkish or Kurdish culture but also, specifically, that of Alevi culture. In December 1988, twelve activists in Hamburg founded an "Alevi Culture Group" (Alevi Kültür Gurubu) with the purpose of working for the recognition 
of Alevi culture and identity in Germany. The group grew quickly and organized a large public festival, the "Alevi Culture Week," which took place in October 1989. This was the first time that an event was explicitly announced in the name of Alevis, and it drew Alevi intellectuals and musicians from Turkey for panel discussions and concerts, and numerous Alevi migrants from not only Hamburg but all over Germany. In the following years Alevi culture centers were established throughout the country. Three years later most of these local associations united in an umbrella organization, the Federation of Alevi Communities. The movement gained further momentum after an Alevi culture festival in the Turkish city of Sivas was attacked by Islamists in July 1993. The hotel housing the participants was set on fire, causing the death of 36 people. This "Sivas massacre" (Sivas katliams) motivated many Alevis in Germany to join the new Alevi movement. Developments towards self-organization in Germany were paralleled by an intensive media discourse on Alevism in Turkey (Vorhoff, 1995).

\section{Recognition, Difference, and the German Public}

Alevi Culture Week can be understood as an event that intended to break with the dissimulation of Alevi identity or takiya, an impression supported by the issuing of the "Alevi Declaration" (Alevi Bildirgesi), which made the claim for recognition explicit. 15 The greater part of the declaration deals with the situation of Alevis in Turkey and demands that Alevis be recognized in Turkey as both equal (i.e. as Muslims and not as a heterodox or non-believers) and different, with particular teachings and traditions. The declaration most particularly calls for the reform of the Directorate for Religious Affairs on the grounds that it negates Alevism; it also is a plea for religious freedom for Alevis to practice their rituals without restriction.

Several paragraphs of the declaration also deal with the situation of Alevis in Germany, where a similar diagnosis is made: Alevism was unacknowledged also in Germany, where public debates on Islam had

15 This declaration is reprinted in Tosun (2002, p. 98-101), while a facsimile of the original declaration can be found in Hamburg Alevi Kültür Merkezi (1999, $\mathrm{p}$ 14). The declaration was drafted by Alevis in Hamburg in cooperation with Alevi intellectuals like Ruza Zelyut in Turkey. In May 1990 a similar declaration signed by many well-known intellectuals and artists (both Alevi and non-Alevi) was published in the Turkish daily Cumhuriyet. This second declaration has been republished in Zelyut (1990, p. 295-301) and Kaleli (1997, p. 182-187). referred exclusively to Sunni Islam and been silent regarding Alevism. But the declaration also states that because of religious freedom in Germany, Alevis have had the opportunity to practice Alevism and to enlighten both their Sunni fellow migrants from Turkey and the German public about it. The declaration demands not only the recognition of Alevism as a separate culture but also mentions differences between Alevis and Sunnis that, it is claimed, allow for easier understanding between Alevis and Germans than might be possible between Sunnis and Germans.

\section{Tanı(t)mak: The Many Meanings of Recognition}

The Turkish verbs tanımak and tanıtmak have become prominent words in the discourse of Alevi organizations in Germany. Tanimak means "to know," "to be acquainted with," "to recognize." Tanitmak is the verb's causative form, thus meaning "to make known," "to cause to be recognized." Alevi organizations made efforts to make Alevism known and recognized, as in Hamburg, where one of the first activities of the newly founded Alevi Culture Center was to organize a series of lectures on Alevism in collaboration with the university, followed by a program of seminars. The organizations were always eager to invite German dignitaries such as members of parliament, mayors, or university professors to their events, since their presence was considered a token of recognition.

Yet Alevis had to deal with the fact that the German public did not distinguish between different kinds of Turks or different kinds of Muslims. In order to become visible as a community and as a form of belief, Alevis had to distinguish themselves publicly from Turkish Sunni immigrants. Thus the contrast they presented in regard to Sunni Islam became the major point of strategic leverage for their process of self-definition. Unlike the strategy frequently used by immigrant communities by which their identity is defined in contradistinction to the native majority, Alevis highlighted not the contrast between Alevi and German culture but rather that between themselves and Sunni Muslims. In doing so, emphasis was placed on the compatibility of German and Alevi cultures. It was especially pointed out what Alevis, in contrast to Sunnis, do not do: fast during Ramadan, go to the mosque to pray five times a day, make the pilgrimage to Mecca, take the Quran as God's literal revelation-nor practice the veiling of women or separation of the sexes. 
At least in the first years of the Alevi movement, then, its members were more eager to explain what they did not do in contrast to Sunnis, than what they did do as defining elements of their own practice. To a certain extent this was a logical outcome of the many ruptures that the Alevi tradition had suffered, migration being only one of many causes of these ruptures. Many Alevis in Germany still have only very rudimentary positive knowledge about Alevism, its teachings and rituals. However, I would like to point out that the discourse on "what Alevis do not do" closely reproduces the dominant discourse on Islam in Germany. That is, in making this contrast they dissociate themselves from the prevalent image of Islam. The headscarf of Muslim women plays a particularly important role in this respect. For many Germans the headscarf signifies not only discrimination against and the repression of women as well as patriarchal family structures in Islam, but also the perceived isolationism and intolerance of Islam in general. 16 It has become the main symbol for all negative stereotypes associated with Islam, expressing what is considered its essential anti-modernity. In order to distance themselves from such stereotypes-and thus from the dominant image of Islam in Germany-Alevis never tire of pointing out that Alevi women do not wear the headscarf. In the context of the gross distinctions put forward by the German foreigner discourse which categorizes Muslims as anti-modern and the "most different" and difficult of immigrants, Alevis position themselves firmly on the side of modernity, that is, on the German side of the divide. They make efforts to represent themselves as non-foreign (or "not so foreign") foreigners.

For Alevis, the intolerant and violent essence of Islam had been most clearly revealed in the 1993 events in Sivas. 17 Sivas is commem-

16 Much has been written about the headscarf as a symbol. For a general discussion see Mandel (1988). Karakasoglu-Aydin (1999) analyzes a specific headscarf-related conflict that was taken to court. On western discourse about Muslim women in general see Kunzler (1999) and Pinn and Wehner (1995). For quite different self-perspectives of young Muslim women in Germany, see Nökel (1999).

17 Based on her fieldwork among Alevis and Sunnis in Berlin in the 1980s, Ruth Mandel writes: "While Alevis abroad are doubly liminal, with respect to both Germans and Sunni Turks, their relative position vis-à-vis Sunnis has undergone a transposition. In West Germany, the reference point of Sunni dominance becomes less and less relevant. Alevis, who in Turkey had defined themselves primarily in opposition to Sunnis, and always in reference to them, have in some respects gradually replaced the latter with Germans in the process of reconstitut- orated annually by Alevi organizations at both the local and the federal level in Germany, in honor of the victims as well as to publicize the dangers of Islamic fundamentalism. In this context, the German public is sometimes criticized for not sufficiently recognizing the difference between Alevis and Sunnis. As stated in a German-language brochure on Sivas published by the Alevi Federation in 2001, "It is perplexing why the German public falls short in recognizing the traditionally democratic outlook of the Alevis, and thus fails to take [this community] into account in discussions on Islam in Germany. In this way the German public overlooks a community of about 600,000 among the immigrants from Turkey, who abide by German laws and introduce a great democratic potential into German society." 18

The essential message in this call for recognition by the authorities and the public is not so much that of Alevism as a distinct culture in need of protection and preservation (as in Taylor's case of Quebecois culture), but rather that of the Alevis' commitment to the presumed universal values of modernity, among them democracy, tolerance, and humanism. The Alevi politics of difference includes the emphasis that Alevis do not make derogatory distinctions among diverse cultures, but accept the dignity and equality of all human beings. The sayings of Hacı Bektas Veli, the most important Alevi saint, are frequently quoted to illustrate the universalist essence of Alevism. One of his most well-known sayings is " 72 millete bir nazarla bak." Literally, it means "view 72 nations with the same look," and is generally interpreted as an appeal to regard all people as equal, thereby expressing an emphasis on equality and tolerance in Alevism. Another adage, "Benim kabem insandir"-"My Kaaba is the human being," is understood as meaning that the human being and human values are at the core of Alevism, not some non-human religious object like the Kaaba in Mecca, as in the case of Islam. Large banners with such sayings frequently decorate the halls in which cultural events commemorating Sivas take place. ${ }^{19}$ In such contexts, the opposition of (Sunni) Islam, represented

gradual replacement of the Alevi-Sunni difference by the Alevi-German difference in Alevi discourses of self-identification. As identifications are historically dynam ic, this contradiction may be explained by the fact that Mandel's research took place before Sivas and mine after it, because Sivas clearly led to a stricter empha sis on the Alevi-Sunni difference among Alevis (Karakaşoğlu-Aydın, 2001, p. 314). $18 \mathrm{AABF}$, (n.d.), p. 6.

19 Such banners are also popular at Alevi events in Turkey, where they signal the Alevi commitment to the secularist ideology of the Turkish republic. 
as violent and intolerant, to Alevism as open, tolerant and humanist, is energetically emphasized.

\section{Institutional Integration and Difference}

Although many Alevis are still not satisfied with the degree of public recognition they enjoy in Germany it cannot be denied that, after more than ten years of organized efforts, the Alevi community has made major advances in this regard. Many more Germans now know that there are both Sunnis and Alevis among the immigrants from Turkey, and have some idea about the difference between these groups. In addition to discursive recognition, institutional integration has also been achieved to a considerable extent. By institutional integration I refer to cooperative relations that have been established between Alevi organizations and various German civil and governmental institutions. According to Soysal (1994), the institutional models and resources provided by the immigration country play an important role in shaping both migrant organizations and the immigrants' incorporation into local society. In this sense, the institutional integration of Alevis in Germany is an outcome of the interaction of Alevi efforts with the German institutional environment.

A central area of concern in this regard is religious instruction; since the early 1990s, religious instruction for Muslim children in German schools has been a topic of debate. Behind efforts in support of such instruction is the rationale that it could help to deter Muslim children from going to "fundamentalist" Quran schools. Due to a great number of political and legal difficulties only a few limited initiatives in Islamic instruction have been implemented so far. Shortly after this issue first emerged, the Alevi position was that their children required instruction specifically in Alevism and not in Islam in general, on the assumption that under the rubric of Islamic instruction only the dominant Sunni or Shiite versions of Islam would be presented.

In 1995 the Alevi Culture Center in Hamburg joined in the "Roundtable for Interfaith Instruction" "Gesprächskreis interreligiöser Religionsunterricht"), a body, sponsored by the Protestant church, in which representatives of Christian, Buddhist, Jewish, Muslim (both Shii and Sunni), and Alevi communities worked together on behalf of joint religious instruction. The German school system is federally organized, with each German Bundesland (province) having its own regu- lations. In Hamburg, unlike in other Bundesländer, there is no denominationally separate Christian religions instruction. The Roundtable was established in order to open religious instruction to non-Christian communities, and interfaith curricula were drafted with the effect that units on Alevism are now also part of the curriculum of religious instruction in Hamburg. Thus Alevism is recognized by both the church and the education authorities. Because of this interdenominational instruction for all, Alevis in Hamburg do not insist on separate Alevi classes. The case is different for other Bundesländer, where Alevis demand separate instruction. Due to legal peculiarities in Berlin, an Islamic federation said to be related to Milli Görüs, the largest Islamist organization of Turkish migrants in Germany, has been granted the right to offer Islamic instruction in the public schools of the city. Consequently, the largest Alevi organization in Berlin applied to offer Alevi instruction and was allowed to teach Alevism in primary schools starting in the summer of 2002. Because this was the first-ever instance of separate Alevi religious instruction in the school, the Berlin authorities' decision was much acclaimed by Alevis.

Institutional integration of the Alevis in Germany can be observed in other fields as well. After a social-democrat/green coalition came to power in 1998, more federal funds have been made available for the purpose of "integrating" migrants and combating racism. The Alevi umbrella organization, the Federation of Alevi Communities, has initiated a number of projects that have benefited from such funds. An Alevi Federation campaign for promulgating information about the new citizenship law of 2000 making naturalization easier was funded by the Federal Ministry for Interior Affairs (see below, section: "Becoming a Citizen, Remaining a Foreigner"). Although the Alevi Federation did not explicitly promote the idea of naturalization within its community, this option was clearly regarded favorably and many Alevis have applied for German citizenship. ${ }^{20}$ Another federally funded project aimed at assisting disadvantaged youths, and more recent-

20 In a recent survey conducted with members of Alevi associations in Hamburg I found that $55.6 \%$ of the respondents had German citizenship includin $9.8 \%$ who possessed dual citizenship $(n=233)$. A comparison of these fies ind the number of immigrants of Turkish citizenship in Germany (1. and the total number of former Turkish citizens by 2000 tal number of former Turkish citizens who had naturalized as Germans by $2000(424,512)$ (Beauftragte der Bundesregierung für Ausländerfragen, 2002 Tab. 6 and 16a) shows that the rate of naturalization is much higher among Alevis than among Turks in general. 
ly, the Ministry of the Interior sponsored an initiative for enhancing dialogue among different religious communities. This project started with a large conference organized by the Alevi Federation in December of 2002 in Cologne. Asked in an interview why the Ministry funded the conference of a religious community, a Ministry representative replied, "We have no problems with the Alevis because they accept our political system. The Alevis are very open." 21 This statement clearly illustrates the success of the Alevi politics of identity in Germany.

The Alevi community in Germany has undergone many changes as a result of this process of engagement with identity politics since the late 1980 s, among them achieving recognition as a religious community in Germany, as the examples of institutional integration presented here clearly indicate. Alevis now participate in interdenominational dialogue with other religious communities and are categorized as a religious community by the German authorities. Yet, when Alevis first began to address the German public in 1989 , the objective was not the recognition of Alevism as a religious community per se. Many of the activists of that time had political roots in Marxism and conceived of themselves as atheists. Consequently they did not define Alevism as a religion, preferring to speak of Alevism as a "culture" (Sökefeld, in press). Of course, there were also religiously oriented Alevis in the associations, and some founded their own organizations. But they remained a minority faction and it was not due to their efforts that Alevism is now more generally defined as a religion. More effective in this respect was the German institutional and discursive environment of recognition. As Alevis defined themselves in contradistinction to (Sunni) Islam, requested Alevi instruction in schools, and cooperated with churches or other religious communities, it made little sense to insist that Alevism was not (or not only) a religion. In conversations with Germans, even self-declared atheists now introduce Alevism as a religious community. In September 2002, the Federation of Alevi Communities approved new by-laws which now explicitly refer to the Alevis as a "religious community" (Glaubensgemeinschaft). ${ }^{22}$ This step

21 The interview was aired on the radio station NDR Info on January 5, 2003 22 At the same time, the Federation has been renamed "Alevitische Gemeinde in Deutschland" (Alevi Community in Germany). In German, the word "Gemeinde" has a religious connotation. For purposes of convenience and because the organization is still called "Federasyon" in Turkish I use the old name "Federation of Alevi Communities in Germany" throughout this paper. was, in any case, required by the German institutional and legal context because in most Bundesländer only religious communities may be granted the right to offer religious instruction in schools.

The degree of recognition and institutional integration achieved so far does not mean that Alevis have been accorded the same formal and legal recognition enjoyed by the dominant Christian churches or the Jewish community in Germany. Except for the Jewish community, a special case because of German history, no minority religious community in Germany has so far achieved this legal recognition. In 1995 the Alevi Federation submitted an application for the status of public corporation (Körperschaft öfentlichen Rechts), the legal status enjoyed by the Protestant and Catholic churches. In contrast to similar applications submitted by Islamic organizations, which have been almost as quickly turned down, the Alevi case is still pending. Thus Alevis find themselves at present in a liminal state of being neither accorded nor denied the final level of formal recognition.

\section{Transnational Politics of Recognition}

In addition to its efforts toward recognition and institutional integration in Germany, the Federation of Alevi Communities never abandoned its quest for formal recognition of Alevism in Turkey. Developments in Turkey of concern to Alevis have always been closely monitored from Germany. Frequently, the Federation of Alevi Communities as well as local Alevi organizations have staged demonstrations, issued press releases, or organized panel discussions to publicize and protest events in Turkey. The language of these texts and events has in most cases been Turkish, and the impact of such activities has mostly remained restricted to the Alevi community, and has had no visible effect on politics in Turkey.

However, a new committee heading the Federation of Alevi Communities has since late 2000 intensified the Federation's efforts toward institutional integration in Germany, combining these efforts with demands for recognition in Turkey. The Federation has raised the issue of Alevis in Turkey in a number of meetings with representatives of the German government and members of parliament, where it was argued that the situation of Alevis in Turkey must be taken into consideration in discussions on Turkey's accession to the European Union. Already in the 1990s, the Alevi Federation had initiated efforts to 
establish contacts with European institutions and especially with members of the European Parliament. In European Commission reports from 2000 and 2001 on Turkey's efforts towards EU membership, the situation of Alevis in Turkey was explicitly mentioned. The report of 2001, for example, notes that

No improvement in the situation of non-Sunni Muslim communities has taken place. The official approach towards the Alevis is unchanged. Alevi concerns have not been taken up by the Presidency of Religious Affairs. Particular Alevi complaints relate to compulsory religious instruction in schools and school books which fail to acknowledge the Alevi identity, and the fact that financial support is only available for the building of Sunni Muslim mosques and religious foundations (Commission of the European Community, 2001, p. 27).

The latest report simply remarks: "There has been no improvement in the status of the Alevis" (Commission of the European Community, 2002, p. 39).

The efforts of the Federation of Alevi Communities in the area of transnational lobbying are known, if to a limited constituency, in Turkey. Hürriyet, the largest selling daily newspaper in Turkey, notorious for its nationalist outlook, heatedly attacked the Federation for working against the interests of Turkey and having become an instrument of the German government and the European Community. The Federation was even said to have betrayed the Turkish nation (Sökefeld, 2002b). However, after the newspaper's owner, Aydın Doğan, visited Germany in the summer of 2001 and met with a number of government officials including the German president, Hürriyet stopped its attacks and the editor responsible for them was dismissed. Shortly before this visit Alevi representatives had discussed the matter in Berlin and it seems they had succeeded in getting this issue onto the agenda for the meetings between Doğan and the German officials.

Important demands made in the struggle for recognition in Turkey include permission to establish civic organizations clearly labeled "Alevi" which could then work for the explicit purpose of promoting Alevism. After several abortive attempts to establish a transnational umbrella organization of Alevis, the Federation of Alevi Communities, together with most of the Turkish Alevi organizations in Germany, formed the "Alevi Bektaşi Kuruluşları Birliği" (Union of Alevi-Bektashi Organizations, or ABKB) in the Summer of 2000 . This umbrella organization has applied for official registration in Ankara. However, registration was refused and the ABKB was officially shut down; further, its committee members were accused of separatist activities. A member of the committee, the chairman of the German Federation, was also required to appear in court. The Federation launched a protest campaign in Germany and, as the chairman was a German citizen, the German embassy in Ankara sent an observer to the trial. The charge against the committee members was dropped, but the decision on closing the $\mathrm{ABKB}$ was upheld.

The organization appealed this decision, framing the issue within the context of Turkey's accession to the EU and addressing it in a meeting with members of the European Parliament in Brussels in February 2002. The debate on Turkey's projected accession and the extent to which the country has met the political and legal criteria became especially intense in the second half of that year, when a decision was due on Turkey's formal candidacy status. In October 2002 the court of appeals referred the decision on the $A B K B$ back to the first instance, which finally allowed the legal registration of the organization. Activists of the Federation interpreted this decision at least in part as an outcome of the EU debate in which Turkey could not permit itself a setback. Although the court decision does not create a precedent, the fact that the transnational umbrella organization is now officially permitted to explicitly call itself "Alevi" is considered a major success in the Alevi struggle for recognition in Turkey.

These examples show that Alevis in Germany have been engaged in constructing a transnational sphere of identity politics and a politics of recognition. They have accomplished this by making use of resources, acquired as a result of the institutional integration they have achieved in Germany and on the European level, to advance their struggle for recognition in Turkey. This case of identity politics is thus not limited to drawing ethnic or religious boundaries and constructing identities, but has entailed complex negotiations and strategies for participation in diverse political and public spheres across national boundaries.

The national frames of reference that operate in Turkey and in Germany define Alevi migrants as Turkish nationals who should not "betray" their nation, in the case of Turkey, and as foreigners who do not really belong there, in the case of Germany. In this context, Alevi 
organizations in Germany have been committed to defining Alevism as a supranational identity, thus independent of particular national identities and interests. Therefore, in contrast to some other migrant organizations, the Alevi Federation is not engaged in preserving the Turkish identity of their migrant members. It has consistently refused to display Turkish national symbols such as the flag, or images of Atatürk, at its conventions. This has frequently been a contentious issue, as the Federation has been repeatedly criticized for this refusal not only by newspapers with a decidedly Turkish nationalist outlook like Hürriyet but also by Alevis themselves. Kemalist ideology, with its particular nationalist elements, was deeply rooted, especially among first-generation Alevi labor migrants. The de-nationalization of Alevism was mainly achieved by the earlier, Marxist-inspired phase of Alevi activism and entailed a strong and lasting opposition to the Turkish state and its ideology. This de-nationalization can also be seen as an outcome of the shift of frame of reference that came about with the introduction of an Alevi politics of difference among migrants in Germany. This move towards difference offered to Alevi migrants new options of identification beyond strict inclusion within the Turkish national frame of reference inherent in both the Turkish nationalist discourse and the German foreigner discourse.

\section{Becoming a Citizen, Remaining a Foreigner}

Concepts of citizenship have occupied a central position in recent debates on migration and multiculturalism. It has been pointed out that in Europe concepts of citizenship and the nation state-and most importantly, the relations between them-have been strongly affected by migration. Alternative concepts of belonging that reach beyond the traditional notion of citizenship based on the ideology of the homogeneous nation-state have been proposed, concepts such as "multicultural citizenship" (Kymlicka, 1995). Indeed, many rights that earlier applied only to the citizens of a state-social benefits, for instance-have been extended to resident immigrants who retain citizenship in their country of origin. Yasemin Soysal (1994 and 1996) has emphasized the emergence of a new "postnational" model of membership that acknowledges fluid boundaries and multiple belonging and is based more on the idea of universal personhood than on the idea of a particular nationality. However, in Germany, as in other states, unrestricted par- ticipation and complete rights are still available only to citizens. Debates on reform of citizenship law in Germany, and especially the abortive attempt to introduce dual citizenship, suggest that postnational models will not be replacing the national model of citizenship any time soon. ${ }^{23}$ On the other hand, the new citizenship law in force since 2000 has made naturalization, and thus the acquisition of all related rights, much easier.

The Alevi Federation has encouraged naturalization so that Alevis might achieve unrestricted participation in German society, and has provided its members with detailed information on the new citizenship law. In a bilingual brochure published by the Federation with financial aid from the German government, it is argued that "in order to have a voice and to achieve equal rights in this country, we must not only learn the language, but must also comply with the conditions of citizenship envisaged by the laws" (AABF, 2000, p. 4). In her preface to that brochure, the Undersecretary of the Ministry of the Interior writes:

Migrants have contributed much to our common home. They have also contributed in making Germany more international and open to the world. The new citizenship law recognizes this achievement. It acknowledges the fact that Germany has changed. For the first time, children of non-German parents . . . will become German citizens by birth. From the first day of their life they will grow up as German citizens in Germany" (ibid., 5).

These sentences capture the new law's rationale of welcoming new citizens and acknowledging that Germany is an immigration country. It is significant that the reform of the law is presented as an acknowledgement of the contribution of immigrants. Thus, the familiar rhetoric of making demands on immigrants (to learn German, to integrate themselves, etc.) has been discontinued here. However, serious conflicts preceding the passage of the law reveal that this new attitude has not yet become common sense in Germany. Although the new law has introduced elements of citizenship rights based on birthplace (jus soli), popular conceptions still hold citizenship as more a matter of "blood." Thus, citizens perceived as "non-Germans" due to their black hair, dark eyes or other details of physical appearance, are generally thought of as for-

23 For a critique of the postnational model, see Kostakopoulou (2001, p. 94) 
eigners and not as German citizens in everyday encounters.

Young Alevis, like many other Turks who have grown up in Germany, lament the persistent perception of themselves as foreigners irrespective of citizenship, emphasizing in interviews that they have never felt "foreign" in Germany. Deniz, a young Alevi student of German citizenship living in Hamburg, had a somewhat different view. When we discussed experiences of home and of foreignness (Fremdheit), she reported feeling especially at home in Altona, a district of Hamburg with a considerable immigrant population, because she does not stand out there. It is different in other parts of the city where she frequently has the feeling that her dark hair draws attention. She then feels categorized as foreigner and regarded with skepticism and distrust. It is this skeptical gaze that makes her foreign even if she herself feels at home in the city. Thus German citizenship is not a sufficient condition for not being viewed as foreigner, and this experience has even been used as an argument against naturalization among Turkish migrants in some cases (Sauer, 2001).

\section{Conclusion}

In this text I have traced the Alevi struggle for recognition from the perspective of its evolution in Germany. But the issue is not restricted to Germany. The Alevi politics of recognition are now situated in a historical context and a discursive space that spans two states and extends even into a realm of supranational integration. Alevi organizations and their activists in Germany exercise their politics of identity transnationally, as illustrated by the close exchanges among Alevi intellectuals in Germany and in Turkey which led, among other things, to the drafting of the "Alevi Declaration." By inviting Alevi intellectuals and artists to cultural events and panel discussions, German Alevi organizations benefited from steady contact with leading figures of the Alevi movement in Turkey, making possible an ongoing exchange of ideas. Yet the new movement of people and ideas between the two communities is two-way, as is evident in the case of a large cultural festival featuring an artistic representation of Alevi history conceived and produced in Germany and first performed in Cologne in May 2000; it then moved to Turkey and was staged in Istanbul two years later in October of 2002.

I have shown that this transnational engagement is not simply a "homeland" perspective signifying non-integration and, at best, divided loyalties. The emergence of an Alevi struggle for recognition in Germany has been closely related to a change in a perspective from that of living in exile or as temporary "guest workers" to that of an immigrant orientation which involves putting down roots and demanding equal rights in the (not so new) country of residence. Moreover, the recent commitment to transnationalize the struggle has been enabled by increased institutional integration within Germany, which made available new resources for a transnational politics of identity.

Recognition is a multidimensional issue, involving a dialectic of complex relationships and negotiations between self and other. The Alevi struggle for recognition in Germany does not simply mirror the analogous struggle in Turkey. In interpersonal encounters as well as in collective processes, recognition involves both equality and difference, the search for acceptance as an equal partner in interaction and communication as well as the recognition of idiosyncrasy. It can be said that the Alevi struggle for recognition in Turkey has centered more on the issue of difference, whereas efforts in Germany have focused primarily on the issue of equality. Citizenship and nationality make an important difference here. In Turkey, Alevis are recognized as full citizens of the Turkish republic and as members of the Turkish nation and enjoy the same general rights as their Sunni fellow citizens. What they struggle for in Turkey is to be recognized as equal but different. In Germany, however, Alevis are clearly marked as different-if not quite in the manner they would like to be. They are perceived as immigrants, Turks, Muslims, foreigners, lacking acceptance as ordinary citizens in many instances. What is at stake in Germany, then, is recognition as different but equal.

\section{REFERENCES}

AABF. 2000. Das neue Staatsangehörigkeitsrecht/Yeni Vatandaşlık Yasası. Cologne: Almanya Alevi Birlikleri Federasyonu. No date. Sivas Şehitlerini Anma Günü. No publishing information.

Aksoy, Asu and Kevin Robins. 2000. "Thinking across Spaces: Transnational Television From Turkey," European Journal of Cultural Studies, 3, pp. 343-365.

2002. "Banal Transnationalism: The Difference That Television 
Makes," Transnational Communities Working Paper WPTC-02-08, available online at: http://www.transcomm.ox.ac.uk.

Baumann, Gerd. 1999. The Multicultural Riddle: Rethinking National, Ethnic and Religious Identities. Routledge: London.

Beauftragte der Bundesregierung für Ausländerfragen. 2002. Daten und Fakten zur Ausländersituation. Berlin.

Becker, Jörg and Reinhard Behnisch (Eds.). 2001. Zwischen Abgrenzung und Integration. Türkische Medienkultur in Deutschland. Loccum: Evangelische Akademie.

Bhabha, Homi. 1994. The Location of Culture. London: Routledge.

Commission of the European Community. 2001. 2001 Regular Report on Turkey's Progress Towards Accession. Brussels: Commission of the European Community.

2002. 2002 Regular Report on Turkey's Progress Towards Accession. Brussels: Commission of the European Community.

Cağlar, Ayse. 1997. "Hyphenated Identities and the Limits of 'Culture,"' in Modood, Tariq and Pnina Werbner (Eds.), The Politics of Multiculturalism in the New Europe. London: Zed Books, pp.169185.

Dressler, Markus. 2002. Die Alevitische Religion. Traditionslinien und Neubestimmungen. Würzburg: Ergon Verlag.

Faist, Thomas (Ed.). 2000. Transstaatliche Räume: Politik, Wirtschaft und Kultur zwischen Deutschland und der Türkei. Bielefeld: Transcript.

Habermas, Jürgen. 1997. “Anerkennungskämpfe im demokratischen Rechtsstaat," in Taylor, Charles, Multikulturalismus und die Politik der Anerkennung. Frankfurt: Fischer, pp. 147-196.

Hamburg Alevi Kültür Merkezi. 1999. Onların Öyküsü. Hamburg: Hamburg Alevi Kültür Merkezi.

Handler, Richard. 1988. Nationalism and the Politics of Culture in $Q u$ ebec. Madison: U. of Wisconsin Press.

Jamin, Mathilde. 1999. "Fremde Heimat: Zur Geschichte der Arbeitsmigration aus der Türkei," in Motte, Jan, Rainer Ohliger and Anne von Oswald (Eds.), 50 Jahre Bundesrepublik, 50 Jahre Einwanderung. Nachkriegsgeschichte als Migrationsgeschichte. Frankfurt: Campus, pp. 145-164.

Jongerden, Joost. 2003. "Violation of Human Rights and the Alevis in Turkey," in White, Paul J. and Joost Jongerden (Eds.), Turkey's Alevi Enigma: A Comprehensive Overview. Leiden: Brill, pp. 71-89.
Joppke, Christian. 1999. Immigration and the Nation-State: The United States, Germany and Great Britain. Oxford: Oxford U. Press.

Kaleli, Lütfi. 1997. Kimliğini Haykıran Alevilik. Istanbul: Can Yaynlari.

Karakaşoğlu-Aydın, Yasemin. 1999. "Eine Analyse der Reaktionen auf den 'Fall Ludin' in der politischen und Medienöffentlichkeit," in Jonker, Gerdien (Ed.), Kern und Rand. Religiöse Minderheiten aus der Türkei in Deutschland. Berlin: Das Arabische Buch, pp. 169. 186.

2001. "Unsere Leute sind nicht so' - Alevitische und sunnitische Studentinnen in Deutschland," in Pusch, Barbara (Ed.), Die neue muslimische Frau. Ergon Verlag: Würzburg, pp. 295-322.

Kehl-Bodrogi, Krisztina. 1992. "Vom revolutionären Klassenkampf zum 'wahren' Islam. Transformationsprozesse im Alevitentum der Türkei nach 1980," Sozialanthropologische Arbeitspapiere, 49. Berlin: Verlag Das Arabische Buch.

1993. "Die 'Wiederfindung' des Alevitentums in der Türkei: Geschichtsmythos und kollektive Identität," Orient, 34, pp. 267-282.

Kostakopoulou, Theodora. 2001. Citizenship, Identity and Immigration in the European Union. Manchester: Manchester U. Press.

Künzler, Eva. 1999. Zum westlichen Frauenbild von Musliminnen. Würzburg: Ergon Verlag.

Kymlicka, Will. 1995. Multicultural Citizenship: A Liberal Theory of Minority Rights. Oxford: Oxford U. Press.

Malkki, Liisa. 1997. "National Geographic: The Rooting of Peoples and the Territorialization of National Identity among Scholars and Refugees," in Gupta, Akhil and James Ferguson (Eds.), Culture, Power, Place: Explorations in Critical Anthropology. Durham: Duke U. Press, pp. 52-74.

Mandel, Ruth. 1989. "Turkish Headscarves and the 'Foreigner Problem': Constructing Difference Through Emblems of Identity," New German Critique, 46, pp. 27-46.

Mihçıyazgan, Ursula. 1990. Moscheen türkischer Muslime in Hamburg. Hamburg: Behörde für Arbeit, Gesundheit und Soziales.

Nökel, Sigrid. 1999. "Islam und Selbstbehauptung - Alltagsweltliche Strategien junger Frauen in Deutschland," in Klein Hessling, Ruth, Sigrid Nökel and Karin Werner (Eds.), Der neue Islam der Frauen. Weibliche Lebenspraxis in der globalisierten Moderne - Fallstudien aus Afrika, Asien und Europa. Biclefeld: Transcript, pp. 124-146. 
Özcan, Ertekin. 1992. Türkische Immigrantenorganisationen in der Bundesrepublik Deutschland. Berlin: Hitit.

Pinn, Irmgard and Marlies Wehner. 1995. EuroPhantasien. Die islamische Frau auswestlicher Sicht. Duisburg: DISS.

Pries, Ludger (Ed.). 1997. Transnationale Migration. Baden Baden: Nomos.

Sauer, Martina. 2001. "Die Einbürgerung türkischer Migranten in Deutschland. Befragung zu Einbürgerungsabsichten und dem Für und Wider der Einbürgerung," in Goldberg, Andreas and Dirk Halm (Eds.), Migrationsbericht des Zentrums für Türkeistudien 2002. Münster: Lit, pp. 165-228.

Sinclair-Webb, Emma. 1999. "Pilgrimage, Politics and Folklore: The Making of Alevi Community," Les Annales de l'Autre Islam, 6, pp. $259-274$.

2003. "Sectarian Violence, the Alevi Minority and the Left: Kahramanmaras 1978," in White, Paul J. and Joost Jongerden (Eds.), Turkey's Alevi Enigma: A Comprehensive Overview. Leiden: Brill, pp. 215-236.

Soysal, Yasemin Nuhoğlu. 1994. Limits of Citizenship: Migrants and Postnational Membership in Europe. Chicago: U. of Chicago Press. 1996. "Changing Citizenship in Europe: Remarks on Postnational Membership and the Nation-State," in Cesarani, David and Mary Fullbrook (Eds.), Citizenship, Nationality and Migration in Europe. London: Routledge, pp. 17-29.

Sökefeld, Martin. 2002a. "Alevi Dedes in the German Diaspora: The Transformation of a Religious Institution," Zeitschrift für Ethnologie, 127, pp. 163-186.

2002b. "Über die Schwierigkeit, dem türkischen Nationaldiskurs zu entkommen: Aleviten in Deutschland und 'Hürriyet." Unpublished Paper.

In press. "Religion or Culture? Concepts of Identity in the Alevi Diaspora," in Kokot, Waltraud, Khachig Tölölyan, and Carolin Alfonso (Eds.), Locality, Identity, Diaspora. London: Routledge.

Taylor, Charles. 1994. "The Politics of Recognition," in Gutman, Amy (Ed.), Multiculturalism: Examining the Politics of Recognition. Princeton: Princeton U. Press, pp. 25-74.

Tosun, Halis. 2002. Alevi Kimliğiyle Yaşamak. Istanbul: Can Yayınları.

Vorhoff, Karin. 1995. Zwischen Glaube, Nation und neuer Gemeinschaft. AlevitischeIdentität in der Türkei. Berlin: Klaus Schwarz Verlag.
1998. "Let's Reclaim Our History and Culture!' Imagining Alevi Community in Contemporary Turkey," Die Welt des Islams, 38, pp. 220-252.

Weiss, Hans-Jürgen and Joachim Trebbe. 2001. Mediennutzung und Integration der türkischen Bevölkerung in Deutschland. Ergebnisse einer Umfrage des Presse- und Informationsamtes der Bundesregi. erung. Potsdam: GöfaK Medienforschung.

Wilamowits-Moellendorff, Ulrich. 2002. Türken in Deutschland - Eins. tellungen zu Staatund Gesellschaft. Arbeitspapier. St. Augustin: Konrad-Adenauer-Stiftung.

Wimmer, Andreas. 2002. Nationalist Exclusion and Ethnic Conflict: Shadows of Modernity. Cambridge: Cambridge U. Press.

Wimmer, Andreas and Nina Glick Schiller. 2002. "Methodological Nationalism and Beyond: Nation-State Building, Migration and the Social Sciences," Global Networks, 2, pp. 301-334.

Zelyut, Riza. 1990. Öz Kaynaklarına Göre Alevilik. Istanbul: Anadolu Kültürü Yayınları. 